\title{
Geological Association of Canada 1999 Annual Technical Meeting Newfoundland Section
}

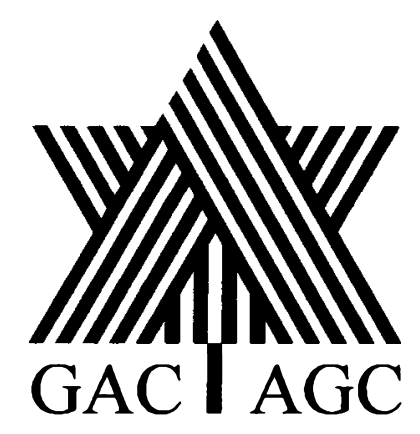

\section{ABSTRACTS}

Resources development and Earth science: environmental and economic issues

\author{
February $22-23,1999$ \\ Department of Earth Sciences \\ Memorial University of Newfoundland \\ St. John's, Newfoundland
}

Abstracts published with financial assistance from the Newfoundland Section of GAC 


\title{
A review of recent research relating to the safe disposal of sulphide-rich mine wastes
}

\author{
Tom A. Al \\ Department of Geology, University of New Brunswick, Fredericton, NB E3B 5A3, Canada
}

The mining industry in Canada makes a very important contribution to the national economy. In the period 1993 to 1997 , the value of exports from the mining industry accounted for approximately $15 \%$ of total national exports. Within specific regions of the country, the significance of the industry to the local economy is much greater. This societal dependence on the economic benefits of mining is often perceived as being in conflict with increasing concerns for the quality of air and water resources, and the health of ecosystems. In response to demands from society for protection of environmental quality, practices of waste disposal in the mining industry have changed dramatically over the past 50 years. In particular, disposal of tailings and waste rock from sulphide-rich ores has caused degradation of water quality in areas that, in some cases, extends far beyond the physical boundaries of mining operations. Prior to the 1980 's, this problem was addressed by constructing confined storage areas for tailings and waste rock; however, it became clear that physical confinement of the waste was not completely effective. Dispersion of contaminants to the surrounding environment remained a problem as a result of geochemical processes that combine with surface and groundwater hydrological transport mechanisms. During the past 15 years, the mining industry and governments have responded by supporting research with the aim of understanding the geochemical mechanisms and hydrological processes that lead to environmental contamination from sulphide-rich mine wastes. This research has contributed to a greater understanding of the mineralogical, chemical, microbiological and kinetic influences on the chemical evolution of mine waste water. The important role of hydrology in the control of sulphide oxidation, containment of metals and acidity within the waste impoundments, and design of more effective waste disposal systems has been recognized. The integration of geochemical concepts with dynamic hydrological systems has resulted in a mature understanding or conceptual model for the geochemical evolution of tailings. The understanding of hydrogeochemistry in waste rock lags behind somewhat, mostly due to the more complex hydrology compared to tailings. The knowledge that has been gained in the past 15 years should allow mining companies and government regulators to design waste disposal systems for new mining operations that will greatly reduce the rate of sulphide oxidation, and prevent the transport of metals and acidity to the surrounding environment.

\section{Reactions of mine-tailings pore water with carbonate mineral surfaces}

\author{
Tom A. Al \\ Department of Geology, University of New Brunswick, Fredericton, NB E3B 5A3, Canada
}

Aqueous geochemistry and analysis of coatings on carbonate-mineral surfaces have been used to study mineralwater reactions in tailings. The coatings were studied with Time-of-Flight Laser-Ionization Mass Spectrometry (TOFLIMS) and Transmission Electron Microscopy (TEM). Water and mineral grain samples were collected from the oxidized tailings, and the unoxidized tailings at depth. The pore-water $\mathrm{pH}$ at the sample locations varies between 3.85 and 6.98. Near the tailings surface, sulphide oxidation decreases the $\mathrm{pH}$, and releases metals such as $\mathrm{Cu}, \mathrm{Pb}, \mathrm{Zn}, \mathrm{Cd}$ and $\mathrm{As}$ to the pore water. Other dissolution reactions release $\mathrm{Na}, \mathrm{K}$ and $\mathrm{Al}$ to the pore water. TOF-LIMS analyses of mineral grains along profiles from the surface coating to the ankerite $[\mathrm{Ca}(\mathrm{Fe}$, $\mathrm{Mg})(\mathrm{CO} 3) 2$ ] substrate indicate decreasing abundances of $\mathrm{Fe}$ with depth at all of the sample locations. In contrast, the abundances of $\mathrm{Ca}$ and $\mathrm{Mg}$ increase with depth below the surface coating. A linear relationship is observed between the abundances of $\mathrm{Fe}$ and $\mathrm{Ca}$ along the depth profiles, suggesting that $\mathrm{Fe}$ replaces $\mathrm{Ca}$ during weathering. This is consistent with
TEM observations of siderite [ $\mathrm{FeCO} 3]$ coatings on the ankerite. A variety of secondary minerals have been identified in the coatings using energy dispersive X-ray spectroscopy and electron diffraction. These include siderite, goethite $[\alpha \mathrm{FeO}(\mathrm{OH})]$, lepidocrocite $[\gamma \mathrm{FeO}(\mathrm{OH})]$ and akaganeite $[\beta \mathrm{FeO}(\mathrm{OH}, \mathrm{Cl})]$. Abundances of the metals $\mathrm{Cu}, \mathrm{Pb}, \mathrm{Zn}$ and $\mathrm{Cd}$ on the mineral surfaces are lowest, and pore-water concentrations are highest, in the low-pH oxidized tailings. Abundances of As on the mineral surfaces are greatest, and pore-water concentrations are lowest, in the low-pH sulphideoxidation zone. These trends $\mathrm{vs} \mathrm{pH}$ are consistent with an adsorption mechanism for attenuation of these elements from the pore water. Abundances of $\mathrm{Na}, \mathrm{K}$ and $\mathrm{Al}$ are greatest at the surfaces of the mineral grains in the low-pH zone which is inconsistent with an adsorption mechanism for attenuation from the pore water. The pore-water concentrations of $\mathrm{Na}, \mathrm{K}$ and $\mathrm{Al}$ in the low-pH zone may be controlled by precipitation or co-precipitation reactions at the carbonate surface. 


\title{
Developing coastal management initiatives in Newfoundland
}

\author{
Martin Batterson \\ Geological Survey, Newfoundland Department of Mines and Energy, St. John's, NF AIB 4J6, Canada
}

This presentation outlines the coastal monitoring project of the Geological Survey of Newfoundland and Labrador, and its impact on coastal management decisions.

The Newfoundland coast is vulnerable to environmental change. Historical incidences of coastal flooding are common, and ongoing recession of unconsolidated cliffs has been reported at many sites. The coastal monitoring program provides baseline data on which to plan development in the coastal fringe. Coastal monitoring has been ongoing since 1993, following on from a Federal initiative that began in 1981. Monitoring sites were established in Conception Bay, Placentia Bay, St. George's Bay, and the southern shore of the Avalon Peninsula. They were designed to define the rates of coastal cliff recession, describe the seasonal variations in beach morphology, and gain an understanding of the coastal environment in Newfoundland.

Results are preliminary, but indicate rates of cliff recession of between 0.0 and 1.25 metres per year (5- to 12-year mean). Erosion is episodic, commonly triggered by a single storm event. Rates are dependent on shoreline orientation, wave climate, slope vegetation, and human interference. Beach morphology shows seasonal changes, from net erosion in the winter to net accretion of sediment in the summer. Seasonal variations in beach morphology and size were noted, to some degree, in all beach systems monitored.

The implications for coastal management strategies are demonstrated by two examples, one from Conception Bay and the other from Placentia Bay. In Conception Bay, cliffs of unconsolidated sediment started to erode following a major storm event in October 1992, with current recession rates of about $0.5 \mathrm{~m}$ per year. Relocating storage sheds and construction of gabions near Chamberlains following the storm cost the Provincial Government in excess of $\$ 30,000$, and loss of shorefront property near Topsail resulted in a new landowner being prevented from house construction. At Point Verde, Placentia Bay, coastal erosion rates of up to $1.0 \mathrm{~m}$ per year (5-year mean) have been recorded in an area of active aggregate removal. Point Verde is at the western end of Placentia Road, and provides natural protection for Placentia from westerly storm waves. Shoreline protection for the community of Placentia has already cost in excess of $\$ 3,000,000$, and the long-term effects of the accelerated removal of Point Verde on Placentia are uncertain. Finding a balance between resource development and their impacts on coastal environments is one of the challenges of any coastal management strategy to be developed for the Province.

\section{Role of postglacial sea level history in targeted archaeological survey}

\author{
Trevor Bell', M.A.P. Renouf ${ }^{2}$, and Tim Rast ${ }^{2}$ \\ 'Department of Geography, Memorial University of Newfoundland, St. John's, NF AIB 3X9, Canada \\ ${ }^{2}$ Archaeology Unit, Memorial University of Newfoundland, St. John's, NF AIB 3X5, Canada
}

The postglacial sea level history of Newfoundland is complex because it was affected by a migrating forebulge generated by the Laurentide Ice Sheet and to a lesser extent local ice caps. Most of the island, therefore, experienced initial relative sea level lowering to below present, followed by a rise to the modern level. The magnitude and timing of these two sea level adjustments are spatially variable and, although not well known, are important considerations in assessing coastal archaeological resources.

The prehistory of Newfoundland is dominated by marineoriented cultures who relied on, and lived close to, the sea. Consequently, the elevation of former sea level at the time of cultural occupation indicates whether potential sites may be located above or below present sea level. Because it is presumed that the results of a reasonably complete (land- based) archaeological survey are representative of the past prehistoric cultures that occupied an area, lacunae in the archaeological record are often treated as real absences and explained in cultural terms, such as migrations or extinctions, and are connected to environmental factors. However, a knowledge of postglacial sea level history, specifically the low-stand, may demonstrate that some of the gaps in the archaeological record are artifacts of sampling. Many of the "missing" sites may be located in the shallow offshore or much closer to modern sea level than previously thought.

In this presentation we report on preliminary results of a pilot project that evaluates whether gaps in the known archaeological record of selected regions of the island can be explained in terms of their relative sea level history. 


\title{
The Canadian Environmental Assessment Act - an overview
}

\author{
Jean Blane \\ Canadian Environmental Assessment Agency, Atlantic Region, \\ 1791 Barrington Street, Suite 1030, Halifax, NS B3J 3L1, Canada
}

The Canadian Environmental Assessment Act sets out in legislation an environmental assessment process for all projects for which the federal government is a regulator, source of funding, land administrator, or proponent. The Act was given Royal Assent in June, 1992, and came into effect in January, 1995. This presentation provides an overview of the Act including its purpose and how the federal environmental assessment process is "triggered".
It addresses key federal environmental assessment requirements and responsibilities. The various types of environmental assessments, including screening, comprehensive study, mediation, and panel review are discussed with emphasis on comprehensive study and panel review. Examples of select mining projects are highlighted.

\section{Environmental management in the Newfoundland offshore}

\author{
David Burley \\ Canada-Newfoundland Offshore Petroleum Board, \\ $5^{\text {th }}$ Floor TD Place, 140 Water Street, St. John's, NF AIC 6H6, Canada
}

The Canada-Newfoundland Offshore Petroleum Board manages the petroleum resources in the Newfoundland offshore area on behalf of the Government of Canada and the Government of Newfoundland and Labrador. Its authority is derived from the legislation implementing the 1985 Atlantic Accord between the two governments. The Board is responsible for administering the offshore petroleum land rights and tenure system, ensuring activities are conducted in a safe and environmentally responsible manner, assessing petroleum resources and ensuring their conservation, and monitoring industrial and employment benefits.

The presentation will begin by briefly describing the Board's legislative mandate, the series of regulations and guidance documents that have been published under its implementing legislation, and the mechanisms by which it interacts with other government agencies.

The presentation will describe the process by which the Board reviews and approves proposed exploration and production activities, focusing upon the latter. The interaction of this process with federal and provincial environmental assessment regimes will briefly be discussed.

The Board's expectations with respect to environmental protection planning for production operations will be enumerated, and selected examples will be given from the environmental protection plan for the Hibernia project.

The presentation will conclude with a description of oil spill response planning for offshore operations, and a summary of recent performance with reference to experience in other jurisdictions.

\section{The Botwood Basin: a new epithermal gold district in central Newfoundland}

\author{
Roland Butler and Brian Dalton \\ Altius Resources Inc., P.O. Box 385, Suite 201, 53 Bond St., St. John's, NF AlC 5J9, Canada
}

The Botwood Basin refers to an area of north-central Newfoundland that is underlain by shallow marine to terrestrial sedimentary rocks and mafic to felsic subaerial volcanic rocks of late Silurian to early Carboniferous age. Numerous gold prospects in the region, some of which were only recently discovered, have been reinterpreted by Altius Minerals Corporation to represent low-sulfidation, hot springstype mineralization. The prospects are exposed at different erosional levels which, in part, accounts for the variety of textures, alteration, and mineralogy observed. However, all prospects exhibit features in common with each other and with established low-sulfidation epithermal models. This class of gold mineralization is an important producer in Nevada, Bolivia, and the southwestern Pacific region. Altius has focused on exploring for this class of mineralization in the Botwood Basin. Early indications suggest that it is an important, newly emerging, epithermal, gold district. 


\title{
Embayed gravel coastlines of southeastern Newfoundland: climate variation, geomorphic response, and management issues
}

\author{
Norm R. Catto \\ Department of Geography, Memorial University of Newfoundland, St. John's, NF AIB 3X9, Canada
}

Much of the coastline of southeastern Newfoundland is marked by embayments fringed with gravel deposits formed under high- to moderate-energy conditions. Although the Newfoundland economy and culture revolve around these embayments, the geomorphic response to environmental variation has not been extensively studied.

Distinctive styles of gravel coastline develop in embayments subject to different environmental conditions, particularly variations in wind activity, precipitation, and landfast seasonal ice formation. Shorelines of open embayments are markedly shore-parallel currents, producing large gravel cusps and longshore drift. Conditions vary between reflective and dissipative along these shorelines, dependent largely upon environmental variations. Interference with coastal facilities, and blockage of river outlets used by migrating salmonids, results from shore-parallel sediment movement combined with fluctuations in fluvial discharge. In contrast, narrow and deep embayments are dominated by shore-normal transport, reflective conditions, and limited return flow to the open ocean. Cuspate structures are elongated normal to the shoreline. Locally-induced pollution tends to remain within the confines of these embayments.

Coastal management is extremely limited in Newfoundland. A lack of understanding and interest in the environmental and geomorphic factors involved in shaping the coastline, combined with jurisdictional uncertainty among levels of government and a failure to formulate comprehensive coastal management policies at all levels, has resulted in environmental problems at several locations.

\section{Environmental assessment is not an "overburden": understanding the process}

\author{
Bas Cleary \\ Newfoundland Department of Environment and Labour, P.O. Box 8700, St. John's, NF AlB 4J6, Canada
}

The Environmental Assessment (EA) Act came into force in the Province of Newfoundland in 1980 and the associated Regulations in the Act were proclaimed in 1984. The purpose of the EA Act is to maximize environmental protection and the quality of life for people by ensuring that if projects are permitted to proceed, they do so in an environmentally acceptable manner. The EA process is not a permitting exercise - it is a planning tool that must be considered at the earliest stages of project development before irrevocable decisions are made. The process is not intended to be insensitive to the needs of proponents but to provide a fair and balanced regime of information gathering, impact evaluation, mitigation identification, and residual impact prediction. This approach will ensure that informed decisions on projects are made in a timely manner.

The EA Act has recently undergone a review with the intent of streamlining the process to make it more efficient and effective without compromising the overall spirit of the Act. The presentation provides an overview of the process, highlighting some proposed reforms while providing some examples of its importance to exploration and mining operations.

\section{Planning for site rehabilitation at Voisey's Bay}

\author{
K.E. Dwyer ${ }^{1}$ and S. Dhargalkar ${ }^{2}$ \\ 'Voisey's Bay Nickel Company Limited, \\ Suite 700, Baine Johnston Centre, 10 Fort William Place, St. John's, NF AIC 1K4, Canada \\ ${ }^{2}$ AGRA Earth and Environmental Limited, 95 Bonaventure Avenue, St. John's, NF AIC 5R6, Canada
}

Early in project planning, Voisey's Bay Nickel Company implemented an Environmental, Health and Safety Management System (EMS), based on the principles of sustainable development, pollution prevention, and continuous improvement. EMS policies are implemented through site Environmental Protection Plans for specific activities and project phases. Plans have been developed for exploration drilling and for infrastructure development. These activities have been conducted in a manner designed to reduce the extent of surface disturbance, either with respect to vegetation removal or exposure of soils and overburden. Full life-cycle stewardship will be ensured by planning for closure from the earliest project phases. Nevertheless, as the project becomes developed into an operating mine/mill, and associated features (roads, docks, accommodation complex, power plant, tailings management areas), areas of land will be disturbed. Site restoration will be approached by progressive rehabilitation, i.e., as sites are disturbed, efforts to encourage revegetation will be implemented.

Organic soils are lacking in the region, and existing vegetative cover exhibits slow growth rates. Nonetheless, a variety of vegetative cover is present, including extensive forested areas. The importing of non-indigenous plant species is usually not compatible with the maintenance of ecosystem 
integrity, hence a research program was initiated to examine the potential of native species in site restoration efforts. Test plots were established in four typical habitat types where previous activities had resulted in terrain disturbance. Plots were subjected to treatments which involved addition of fertilizer and humus. A selection of native species were planted in test and control cells, and growth rates measured throughout the vegetative season. Shoot growth and root growth were measured to determine whether the cuttings had become established, the extent of growth achieved over the test period, and the effect of added fertilizer and humus. Preliminary results indicate that deciduous species displayed the best growth characteristics. The effect of fertilizer addition produced mixed result; however, the test period may have been too short to demonstrate effects. Future sampling from the plots can address over-wintering success and longer term trends.

\title{
The role of hydrogeology in developing effective mine water control programs in fractured porous rocks
}

\author{
John E. Gale ${ }^{1,2}$, R. MacLeod ${ }^{2}$ and G. Bursey ${ }^{2}$ \\ 'Department of Earth Sciences, Memorial University of Newfoundland, St. John's, NF AIX 3X5, Canada \\ ${ }^{2}$ Fracflow Consultants, 154 Major's Path, St. John's, NF A1A 5A1, Canada
}

Many open pit and underground mining sites are characterized by overburden of variable thickness that is underlain by fractured bedrock. Fractures or discontinuities in these bedrock units exist at different scales, including large scale to intermediate scale structures such as faults and shear zones, that range in length from tens of metres to kilometres, intermediate to small scale features such as bedding planes and joints that range from metres to tens of metres in length and the small scale fissures that have length scales of $\mathrm{mm}$ to $\mathrm{cm}$. In fractured porous rocks, where the matrix can have significant porosity and permeability, the fracture system usually provides the main conduits for flow while the combined matrix and fracture system provides the storage.

The flow properties of fractured porous rocks are highly dependent on fracture type, effective stress conditions, stress history, and the geometry of the fracture system. The highly variable nature of the fracture system generally produces strong anisotropy and heterogeneity in the fracture transmissivity over the area of interest. Interpretation of rock mass transmissivities from wells completed in these rock masses must reference models other than the classical radial flow models. Properly located observation wells are essential to both the interpretation of the well test data and to the assessment of the extent and shape of the effective dewatering zone and the magnitude of optimum well interference effects. In addition, the concentration of the rock mass transmissivity in a few fractures can produce high fluid velocity and significant "skin effects" or wellbore losses that significantly reduces the efficiency of the water control wells. Effective mine dewatering or mine water control in such rock masses requires careful well location, proper well design and construction followed by vigorous well development to minimize well losses.

In complex hydrogeologic settings, such as those presented by most fractured rock masses, 3-D numerical flow and transport models are essential for proper decision making in locating water control wells and in determining operating efficiencies. Numerical models provide estimates of groundwater flowpaths and, when used in conjunction with groundwater geochemistry and isotope data, identify sources of recharge and provide the possibility of either remediation, control or management by modifying the local groundwater gradients.

\section{Environmental standards - facts and fantasies}

\author{
Alex Harris \\ Burin Minerals Limited, P.O. Box 337, St. Lawrence, NF AOE 2VI, Canada
}

Environmental management should be based on facts, not pressure from environmental interest groups. With acid rain, ozone, and pesticides, there is a dichotomy between scientific data and public opinion. For example, termites produce 50 billion tons of greenhouse gases annually, 10 times more than burning fossil fuels, and the quantity of toxic materials spewed into the air from just three volcanoes exceeds all the air polluting materials produced by man. Changes in the ozone layer are related to chloride chemistry. Volcanism and seawater evaporation each contribute about 500 times the annual atmospheric chloride from production of chlorine and fluorocarbon compounds.
The $\mathrm{pH}$ of rainwater in pristine regions is 5.0 to 6.6. Two strokes of lightning over one square kilometre produce enough nitric acid to make $2 \mathrm{~cm}$ of rain with $\mathrm{pH}$ of 3.5 .

The banning of DDT was based on allegations that DDT caused the death of birds, that it was so stable that it could never be eliminated from the environment, and that it might cause cancer. Similar unsubstantiated charges have been used against asbestos, PCBs, dioxin, and Alar. A person would have to eat 28,000 pounds of apples every day for 70 years to produce tumours from Alar residues.

Hot springs and mineral water resorts have elevated radioactivity. There is no proof that this radiation makes 
people feel better, but there is no evidence that it has any ill effects.

An analysis of radon exposure versus lung cancer found that the correlation was negative at low levels - the more radon, the less lung cancer. Results from over 1,000 separate studies are consistent: There is a threshold or cutoff point below which radiation is either harmless or beneficial. Low doses give accelerated development, increased resistance to disease, greater reproductivity, and longer lifespan. Low doses do not give proportionate harmful effects.

\title{
Incorporating traditional ecological knowledge into environmental assessments - Labrador experience
}

\author{
Bevin R. LeDrew and Tony Williamson \\ AGRA Earth and Environment Ltd., 95 Bonoventure Ave., St. John's, NF AIC 5R6, Canada
}

Traditional Ecological Knowledge (TEK) represents a way of viewing the world as seen by indigenous people whose cultures rely extensively on natural resources, and whose economy is described as "subsistence-based". In many regions of Canada, and especially in the north, aboriginal cultures retain knowledge about natural processes, organized in a manner consistent with traditional belief systems and spirituality. Thoughts are organized in a manner which reflects this set of beliefs, and establishes cause and effect relationships in a manner supported by long term observations of natural phenomena. This knowledge base covers subjects such as weather and climate, characteristics of food sources (including mystical and medicinal properties), ecological relationships, animal behaviour, and sustainability.

TEK has become important as a key requirement in environmental assessment. It is needed in providing an adequate description of the existing environment, i.e., the baseline against which anticipated project changes will be compared. TEK must be taken into account in defining the scope of an environmental impact assessment. The process of issues scoping must take into account the perceptions and values of affected aboriginal peoples, and they are required to be consulted early in the environmental impact assessment process. TEK can be important in prediction of environmental effects, as well as the identification of acceptable and effective mitigation and monitoring measures. TEK is regarded as a body of knowledge which is communal, rather than individual property, therefore the informed consent of the community is required as an essential prerequisite to any information collection activity. It is important to adhere strictly to protocols which are in place to provide this consent.

While TEK has become an essential ingredient of environmental impact assessments where projects can affect indigenous people, there is little documented advice available from government regulatory or research agencies. The Voisey's Bay Mine/Mill Environmental Assessment provided two sets of experience which illustrate the challenges associated with incorporation of TEK into an Environmental Impact Statement. The experience with Labrador Inuit Association showed the greater promise. Key ingredients of success included: the selection of capable and mutually acceptable research staff who facilitated the process; direct personal interaction between company officials and residents over periods of several days, and on several occasions; approaching interactions without preconceptions and with and attitude of mutual respect; and spending time in the country, where knowledge and skills can be best communicated.

\section{Avalanche hazard in mine development}

\author{
D.G.E. Liverman', M.J. Batterson', D.M. Taylor' and J. Ryan ${ }^{2}$ \\ 'Geological Survey of Newfoundland and Labrador, Department of Mines and Energy, \\ P.O. Box 8700, St. John's, NF AIB 4J6, Canada \\ ${ }^{2}$ Department of Geography, Memorial University of Newfoundland, St. John's, NF AIB 3X9, Canada
}

Mine development has different constraints to other infrastructure construction, in that there is generally little choice as to siting of the major structures associated with the mine. The choice of site is governed by the position of the deposit, rather than any other considerations. Thus mines and mining communities have often been located under steep slopes, making them vulnerable to slope hazards of various sorts and, in Newfoundland, particularly avalanches. Archival research shows that there have been at least five major avalanches impacting on mining operations, with four incidents resulting in deaths. Fourteen fatalities are known in total - four occurred in the course of actual mining operations, and the others due to avalanches striking residences. All the incidents took place prior to 1914, suggesting a change in the nature of mining operations since that time, with a transfer of exploration efforts towards the interior of Newfoundland (where slopes are generally less). Modern transportation mechanisms allow mining communities to be sited greater distances from the mine site, and in less hazardous positions. Northern Labrador has a combination of high relief, steep slopes, and high snowfall. Thus avalanche hazard must be considered in planning any mine infrastructure in this area, as well as in exploration efforts. 


\title{
Environmental control - Nugget Pond: from environmental assessment to complete compliance with environmental discharge criteria
}

\author{
Steve McAlpine \\ Richmont Mines Inc., P.O. Box 580, Baie Verte, NF AOK 1B0, Canada
}

Safe and efficient production while maximizing the protection of the environment has been a goal and achievement of the Nugget Pond gold mine on the Baie Verte Peninsula, Newfoundland. Environmental issues were a top priority from the earliest planning stages. Tailings disposal and waste water control are the key environmental issues during the production period. All waste rock is being recycled underground as backfill. The tailings are subjected to the INCO-SO ${ }_{2}$ air destruction process prior to being released to the tailings pond, where they are submerged; therefore, acid- drainage will not be an issue. All outflow waters from the environmental control system are tested on a daily basis, and have been compliant with the operation's Environmental Certificate of Approval.

A reclamation plan has been established based on the guidelines in the Certificate of Approval to operate the mine and mill. Some reclamation, including tree planting, recycling and surface contouring has been completed even at this early stage of the operation.

\section{The Pancanadian et al. Shoal Point K-39 well - exploration setting and potential outcomes}

\author{
Steven M. Millan ${ }^{1}$, Cabot Martin ${ }^{2}$, Patrick Laracy ${ }^{3}$ \\ 'Imperial Venture Corp., P.O. Box 6232, St. John's, NF AIC 6J9, Canada \\ ${ }^{2}$ Vinland Petroleum Inc., Suite 200, 430-434 Water Street, St. John's, NF AIC 5P5, Canada \\ ${ }^{3}$ Vulcan Minerals Incorporated, 366 Thorburn Road, St. John's, NF AlB 4RI, Canada
}

The K-39 well was spudded on the Port-au-Port Peninsula on February $9^{\text {th }}, 1999$. Its surface location is on Shoal Point with a subsurface target under Port-au-Port Bay. The licensed total depth is 2440 meters and the estimated well cost is $\$ 10$ million.

The drilling of this well represents a restart of exploration activity in Western Newfoundland after an initial round of drilling that resulted in one geological success and three dry holes. The K-39 well is being drilled in the light of the subsurface knowledge gained by the previous wells plus extensive new seismic data, which was acquired approximately 12 months ago. By reason of the improved database, the K-39 well is viewed as having a 1 in 10 chance of commercial success (according to PanCanadian). Their average expectation is for a discovery of 130 million barrels of recoverable oil.

The initial well in the area, the Hunt et al Port-au-Port \#1, was a geological success that established the presence of producable hydrocarbons and the existence of a petroleum system. This well ignited the play and generated very high hopes for the area and the basin. These hopes were considerably dampened by the subsequent dry holes.
As a result of these disappointments and external factors such as low oil prices, interest in the Western Basin has been minimal for the past two and a half years. This low level of interest, in turn, has seriously affected the willingness and ability of companies to commit funds or raise capital to fund new exploration projects. Within this context, the K-39 well will be closely followed by both professional explorationists and the investing public for its perceived impact on the future of the area.

Well information, through the limitations of the appraisal tools and the complexity of the natural subsurface setting, is often not definitive and usually requires interpretation. Further, government and securities regulations provide for confidentiality periods and constrain public statements by operators. Professional explorationists are likely to interpret results from the well differently to members of the investing public.

In this paper, the authors examine a range of possible exploration outcomes, estimate the probability of their occurrence, and look at their impact on the play.

\section{Practical application of Provincial and Federal requirements (what is an EIS and why do I need one?)}

\author{
Kathy Penney and Colleen Leeder \\ Jacques Whitford Environment Limited, 607 Torbay Road, St. John's, NF AlA 4Y6, Canada
}

Mines and mills, and features of mineral exploration are subject to the Newfoundland Environmental Assessment Act (NEAA) and may be subject to the Canadian Environmental Assessment Act (CEAA). Requirements of both processes vary from project to project depending on the type of project, its location, and associated environmental issues. The role of a project proponent is to present information on the environmental effects of a project prior to its commencement. The legislated requirements can range from presentation of existing information with no public consultation to collection 
of environmental baseline data with extensive data analysis and comprehensive public involvement. This paper will describe how legislated requirements can be practically applied by proponents.

Both $N E A A$ and $C E A A$ require a description of the project and existing environment, proposed mitigation measures (as appropriate), an assessment of environmental effects, and proposed monitoring plans (or follow-up) as appropriate. The description of the existing environment can be broadly categorized into: atmospheric, terrestrial, freshwater, marine, archaeological, and socio-economic. The data collection methods and analytical tools will be dependent on the scope of work required. Depending on the level of the environmental assessment, other requirements may include: purpose of the project, an assessment of alternatives, and a program for public consultation.

Project proponents should be aware of scheduling and budgeting implications of $C E A A$ and $N E A A$ when work plans and budgets are being prepared, and be in a position to anticipate the scope of work required. The role and responsibilities of proponents will be discussed.

\title{
Long Pond Barachois: an overview
}

\author{
Don Pittman \\ Department of Geography, Memorial University of Newfoundland, St. John's, NF AlB 3X9, Canada
}

Long Pond Barachois, Conception Bay, South, Newfoundland, is a shore-parallel gravel barrier that measures approximately $2 \mathrm{~km}$ in length. The barachois separates Long Pond, which consists of two basins joined by a tidal channel, from Conception Bay. The main body of the barachois consists of a single crested storm berm, fronted by a relatively narrow intertidal swash zone. Burnt Island, a small glaciofluvial outwash deposit, serves as an anchor point for the barrier. Long Pond Barachois has developed under a variety of coastal processes, and this diversity is reflected in the barrier morphology. These processes include shore parallel currents, driven by prevailing southwesterly winds, storm waves and swells from the north east, and a relatively rapid rate of sea level rise.

The barachois has also been affected by anthropogenic development. The construction of an extensive beach wall to the south during the 1890 's decreased the amount of available sediment. This allowed formation of a gut, which migrated to the southern end of the beach. The gut was then stabilized by the addition of shore-normal breakwaters on either side. This not only changed the local water chemistry, but facilitated tidal currents within the lagoon.

The barrier morphology can then be generalized into four main sections. The southern margin is prograding, mainly as a result of sediment trapping by a breakwater. This is the widest section of the barrier. The section fronting the tidal channel has been narrowed by scouring of the back-barrier sediments by the channel. This section contains the narrowest area of the barrier. The outer margins of both sections are dominated by beach ridges. The third section, located between the tidal channel and Burnt Island, experiences periodic overwash activity, associated with the formation of beach cusps. The northernmost section, stretching from Burnt Island to the mainland, is transgressing, and shows more evidence of overwash. The elevation decreases from south to north, as does the storm berm slope.

\section{Management of sulphur dioxide emissions from the Holyrood thermal generating station}

\author{
Francis L. Ricketts and David Kiell \\ Newfoundland and Labrador Hydro, P.O. Box 12400, Columbus Drive, St. John's, NF AlB 4K7, Canada
}

Newfoundland and Labrador Hydro (Hydro) owns and operates a 500 megawatt thermal generating station (HGS) near Seal Cove on the shore of Conception Bay, Newfoundland. HGS consists of three units and burns Bunker $C$ fuel to generate electrical energy. Combustion products are

emitted through three stacks and include: sulphur dioxide, particulate matter, nitrous oxides, carbon dioxide, and carbon monoxide. Hydro has management and tracking programs associated with these emissions. Programs related to sulphur dioxide emissions will be discussed in further detail.

\section{The changing role of environmental risk assessment in Newfoundland}

\author{
H. Scott Schillereff \\ Jacques Whitford Environment Limited, 607 Torbay Road, St. John's, NF AlA 4Y6, Canada
}

Risk assessment is commonly applied for rational decision-making in most business areas (e.g., financial, legal, marketing, production, asset performance, and catastrophic event consequences). Within the industrial sector, formal risk management based on quantitative risk assessment has developed to an advanced level as a result of high financial risks associated with care and control of contaminated sites, and there has been increasing shareholder, public, and regulator scrutiny. Environment risk assessment is one implementation of the universal risk assessment methodology. It evaluates health risks posed to specific human and ecological receptors due to potential exposure to known 
hazards. Fundamental risk analysis methods are described, along with various industrial and environmental risk management tools and techniques. Conversion of risk assessment outputs into forms actually useful to non-technical corporate users is described. In the past, environmental risk management has focussed on removing a hazard. Presently, risk reduction measures include limiting receptor exposure to a hazard, which in some cases may be left in place. There is already a shift of regulator expectation away from the concept of largely unattainable pristine cleanup to a more rational stance of acceptable risk reduction. In the future, we see improved government and private sector partnering in the development and implementation of risk approaches for sites contaminated by the wide range of common contaminants (e.g., petroleum hydrocarbons, PAHs, metals, PCBs, pesticides). This, coupled with effective risk communication, should lead to greater public confidence in site remediation efforts and the general state of the environment.

\title{
Source tracing of atmospheric sulphur: Newfoundland perspective
}

\author{
Moire A. Wadleigh \\ Department of Earth Sciences, Memorial University of Newfoundland, St. John's, NF AIX 3X5, Canada
}

Sulphur in the atmosphere is derived from both natural and anthropogenic sources. A proper assessment of the relative importance of these sources in any area requires the ability to differentiate between them. Stable sulphur isotopic signatures can achieve this differentiation. Newfoundland lies directly in the path of prevailing air mass movement transporting pollutant sulphur eastward from the large emission sources on the eastern North American mainland. The overall objective of this work was to measure the sulphur isotopic composition of the atmosphere across the island of Newfoundland in order to assess the degree to which the island is being affected by long-range transport of anthropogenic sulphur from eastern North America, and/or local pollution sources. A contour map based on the analysis of over 100 samples of epiphytic lichen and precipitation shows a gradient of sulphur isotopic composition, with values decreasing from the coast to the interior of the island. It also shows regions of low isotopic composition, typical of anthropogenic emissions, corresponding to the city of St. John's, the Come-By-Chance oil refinery, mining areas, and fossil fuel powered pulp and paper mills in central and western Newfoundland. The study strongly suggests that the isotopic composition of sulphur in the Newfoundland atmosphere is influenced more by the ocean (sea salt sulphate) and local anthropogenic activities in the province, than by long-range transport of continental North American sulphur.

\section{Chemostratigraphy and alteration at Lucky Strike - potential application to implication for the Buchans camp}

\author{
L.S. Winter', D.H.C. Wilton ${ }^{l}$, and J. Tuach ${ }^{2}$ \\ 'Department of Earth Sciences, Memorial University of Newfoundland, St. Johns, NF \\ ${ }^{2}$ Buchans River Ltd., Suite W-210, Ballyrou Place, 280 Torbay Road, AlA 3W8, St. John's, NF
}

Utilizing the ratios of high field strength immobile elements $\left(\mathrm{Zr}, \mathrm{Nb}, \mathrm{Y}, \mathrm{Sc}, \mathrm{TiO}_{2}, \mathrm{P}_{2} \mathrm{O}_{5}\right)$ at least four distinct lithological types are recognized in the vicinity of the Lucky Strike deposit. These include tholeiitic andesitic-basalt, transitional andesitic-basalt, and a genetically related transitional dacite-rhyodacite, as well as calc-alkalic daciterhyodacite. The tholeiitic to transitional units are in the footwall to the ore horizon only, whereas, the calc-alkalic units represent the immediate hanging wall sequence. This transition from units with tholeiitic/transitional affinity to younger rocks with calc-alkalic affinity demarcates a distinctive petrogenetic (and tectonic?) boundary within the evolution of the Ordovician arc sequence where geological conditions were optimal for VMS formation.

Based on the MacLean method using immobile element ratios as monitors, mass balance calculations for major oxides, as well as some low field strength elements ( $\mathrm{Ba}, \mathrm{Rb}, \mathrm{Sr})$, indicate that many of these elements were significantly mobile. In the mafic rocks, two types of alteration are identified from mass changes: sericitization (addition of $\mathrm{K}_{2} \mathrm{O}$, removal of $\mathrm{Na}_{2} \mathrm{O}, \mathrm{CaO}$ ), and chloritization (addition of $\mathrm{MgO}$, removal of alkalis). Most mafic rocks are also silicified. Felsic rocks most commonly are sericitized and show losses of $\mathrm{Na}_{2} \mathrm{O}, \mathrm{CaO}$ and $\mathrm{SiO}_{2}$, but with gains of $\mathrm{K}_{2} \mathrm{O}$ up to $\sim 3 \%$. Gains of more than $3 \% \mathrm{~K}_{2} \mathrm{O}$ coupled with $\mathrm{Na}_{2} \mathrm{O}$ loss are indicative of $\mathrm{K}$-feldspar - sericite alteration, commonly known as "white rhyolite". Only a few of the felsic rocks sampled have significant chlorite-carbonate development and these are geochemically distinguished by $\mathrm{MgO}$ and $\mathrm{CaO}$ enrichment. These chlorite-carbonate altered rocks are confined to stockwork zones immediately underneath the ore horizon.

Due to structural juxtaposing of stratigraphy, the depth extent of altered footwall rocks cannot be determined. Alteration is present to a depth of $\sim 320$ meters, however, and involved complete feldspar destruction and generation of chlorite-quartz-sericite assemblages. Up to 100 meters below the ore horizon, intense chlorite - pyrite \pm quartz \pm carbonate stockwork alteration is developed that is transitional into quartz stockwork and basemetal-sulphide mineralization at the core of the system. In the hanging wall, feldspars phenocrysts in the host rocks are commonly only partly altered and are generally unaffected after tens of metres.

The results of this study have direct applications to exploration for VMS deposits in the Buchans camp. 
Geochemical discrimination diagrams can be used to identify relative positions with respect to ore horizons within a volcanic stratigraphy. Hydrothermal alteration does not affect elements used in this classification and data can be obtained by relatively inexpensive analytical methods such as pressed powder pellet X-ray fluorescence. Other mobile major and trace element data can then be used to classify alteration styles within these units and further refine exploration ideas. Prospective zones of hydrothermal alteration in the Buchans area will be compared to the data from the Lucky Strike area. 